\title{
Perception of Social Innovation among Management Students
}

\author{
Judita Peterlin \\ University of Ljubljana, Faculty of Economics, Slovenia \\ Vlado Dimovski \\ University of Ljubljana, Faculty of Economics, Slovenia \\ Daniela Garbin Praničević \\ University of Split, Faculty of Economics, Croatia
}

\begin{abstract}
The goal of our paper is to develop and present a novel methodology of social innovation among management students. In our paper we present the understanding of the management students' perceptions about social innovation which represents the first stage of developing and adjusting social innovation methodology to management education curriculum at a business school. Social innovation methodology is researched and implemented. We gained results in two research phases; in 2014 and 2015. Altogether, we present the results of social innovation methodology by analyzing the questionnaire results of 239 students. Social innovation achieves a systematic change for the benefit of people and planet by using specially adjusted methods for an identified social challenge. Social innovation methodology and its usage in management education setting proved to be an under-researched and highly useful didactic tool to empower students about global and local management issues.
\end{abstract}

Keywords: social innovation methodology, sustainable development, empowerment, management education, student awareness

JEL classification: A22, 130, M10, M14

Acknowledgments: We wish to thank European Social Fund.

\section{Introduction}

Social innovation (Osburg et al., 2013; Goldsmith, 2010) is a novel methodological approach that means "innovation in social relations" (Moulaert et al., 2015, p. 2). Social innovation is an ongoing field of research for three reasons (Moulaert et al., 2015, p. 3): 1) most of the social problems in our societies are far from being solved, and new ones are likely to arise as globalization, competitive pressures and freemarket policies will continue to shape the socio-economic functioning of the society; 2) research methodologies on social innovation are far from being stabilized or agreed upon by all researchers and stakeholders; 3) how to position research about social innovation in social setting: cross learning and dialogue among researchers and field practitioners need to advance.

Our motive to carry out this research was to spread the awareness of social innovation among our students (Kezar et al., 2011) and see how well they are aware of social entrepreneurship, therefore our research question was: "How do business students understand social innovation?" Purpose of the paper is to develop and present a novel methodology of social innovation among management students (Hargreaves et al., 2006). In order to gain potential usefulness of proposed social 
innovation methodology, students first need to be exposed to real life examples (Bertoncelj et al., 2011) and inspiring cases of local and social entrepreneurs (Boss, 2016).

We present the understanding of the management students' perceptions about social innovation which represents the first stage of developing and adjusting social innovation methodology to management education curriculum at a business school. We present the results of a longitudinal research, during 2014 and 2015, by analyzing the results of 239 students.

\section{Social innovation methodology}

Social innovation incorporates several different techniques, such as participant observations, ethnography, interviewing, life histories, focus groups, visual analysis, landscape interpretation, archival research, textual and discourse analysis in a unique combination according to the needs of the research project (Konstantatos et al., 2015, p. 275). Qualitative techniques aid the need to uncover relations which we cannot easily observe, however they do inform and direct "socially creative initiatives" (Konstantatos et al., 2015, p. 279). "The ontology of knowledge in social innovation analysis and practice calls for a researcher's positioning towards the genesis of the views of the world as a social process and the outcome as socially reproduced, therefore never reaching completion and always critically reinterpreted"(Moulaert in Konstantatos et al., 2015, p. 282). "Assets and strengths based development approaches have research strategies within their practice which link general and local relations and conditions to knowledge to enable action. The strategies most commonly used derive from qualitative, critical action research methodologies and appreciative inquiry methods; methods which resonate strongly with the concerns of social innovation research" (Kunnen et al., 2015, p. 285). "Social innovation clearly shows that research cannot be the responsibility of a single social science discipline, nor entrusted to theoretical and empirical analysis only, but that it has, instead, a strong action orientation" (Moulaert et al., 2015, p. 14).

Peter Drucker identified social innovation as the new dimension of management science (Moulaert et al., 2015, p. 14) and used it as the tool to satisfy the need for human synergies within management. Social innovation is path dependent and contextual as it is "a scientific concept that should include the search for improvement of human existence, a better equilibrium in living together, together within the evolution of relations between human beings and the initiation of actions to improve the human and natural condition (Moulaert et al., 2015, p. 16-17).

\section{Methodology}

We used qualitative methodology (Denzin et al., 2005), specifically an open-ended questionnaire as part of the structured social innovation methodology (Murray et al., 2010). We advanced the first year's questionnaire and in this paper we provide the results of how students perceive and understand social innovation in their environment. Social innovation methodology was implemented as the driver of transdisciplinary research and a guide for collective action (Klein, 2015, p. 9). We gained from societal perspective and epistemological perspective as social innovation is considered an alternative development strategy (Klein, 2015, p. 9). 


\section{Results}

Our result, gained from 104 students of management in 2014 state that students connect environmental protection with waste management and recycling, the most frequently (Figure 1).

Figure 1

Word Frequency of Environmental Protection Perception among Students

Source: Author

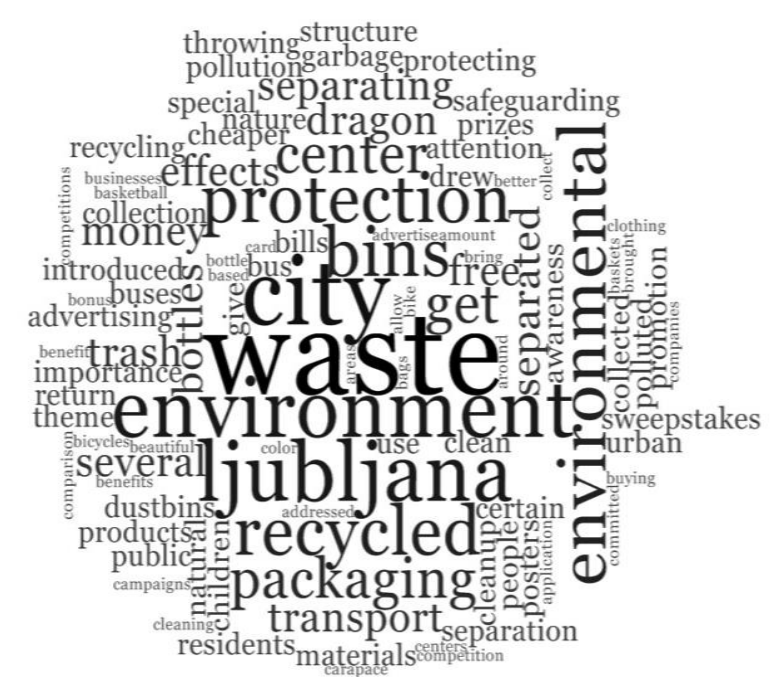

Students perceive social innovation mainly as a systematic advancement of society (Table 1). It is shown that social innovation is seen as targeted mostly at social issues, neglecting somehow natural resources. 
Table 1

Main themes of students' social innovation perception

\begin{tabular}{|c|c|c|}
\hline Themes & Proof Quote & Area of Interest \\
\hline $\begin{array}{l}\text { Social Responsibility of a } \\
\text { Company }\end{array}$ & $\begin{array}{l}\text { "self-sufficient, sustainable } \\
\text { company" } \\
\text { "strengthening of the society } \\
\text { through new ideas, strategies, } \\
\text { concepts that solve the needs of } \\
\text { the society" }\end{array}$ & Business Model \\
\hline 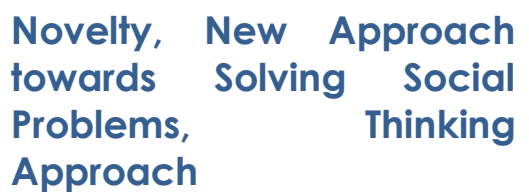 & $\begin{array}{l}\text { "thinking together in order to } \\
\text { contribute to the advancement } \\
\text { of the society as a whole" } \\
\text { "modernization" }\end{array}$ & Creative Thinking \\
\hline Social Consciousness & $\begin{array}{l}\text { "consciousness of the society } \\
\text { that it deals with contemporary } \\
\text { challenges and searches for } \\
\text { solutions in an innovative way" } \\
\text { "good for the society, humanity" } \\
\text { "idea useful for advancement } \\
\text { and better future" } \\
\text { "integrity of social development" } \\
\text { "novelty, advancement in } \\
\text { society and environment that } \\
\text { encourages us towards } \\
\text { efficiency and creativity" } \\
\text { "better quality of life" }\end{array}$ & Society \\
\hline $\begin{array}{ll}\text { Environmental } & \text { Protection } \\
\text { and } & \text { Ecological } \\
\text { development } & \end{array}$ & $\begin{array}{l}\text { "protect the environment and } \\
\text { do something useful for your } \\
\text { health" } \\
\text { "development of a society so } \\
\text { that the society lives in a better } \\
\text { environment" }\end{array}$ & Ecology \\
\hline $\begin{array}{l}\text { Improvement of Social } \\
\text { Relations }\end{array}$ & $\begin{array}{l}\text { "solving social problems in a } \\
\text { sustainable way" } \\
\text { "something that benefits the } \\
\text { society, not only individuals" } \\
\text { "establishing a better life for our } \\
\text { successors" } \\
\text { "achievable growth for all" } \\
\text { "innovation that benefits the } \\
\text { masses and is achievable to all" }\end{array}$ & Sustainability \\
\hline $\begin{array}{l}\text { Entrepreneurial Idea that } \\
\text { Helps Society }\end{array}$ & $\begin{array}{l}\text { "change, novelty that is with the } \\
\text { help of entrepreneurship } \\
\text { implemented into the society for } \\
\text { the achievement of better social } \\
\text { conditions" } \\
\text { "increasing the productivity of } \\
\text { the economy" }\end{array}$ & Entrepreneurship \\
\hline
\end{tabular}

Note: Data gathered in 2015 on a sample of 135 students.

Source: Own questionnaire

\section{Discussion}

As demonstrated, we can firmly state that we need to work further on raising awareness about social innovation methodology, that can serve to our students as a learning tool but also as a methodology that can help them identify the needs of their clients and stakeholders. Students showed maturity in their relationship towards social problems, however due to the name "social" in social innovation we need to 
make them aware that social innovation deals with Global goals that also deal with the creative protection of natural resources.

Main themes highlight that students understood the essence of social innovation that is its systemic orientation. Nevertheless, further research needs to be taken to establish a common definition of social innovation as for now many definitions coexist and we can find common ground in the sense that all definitions suppose the following three key mechanisms that are driving contemporary social innovation (Center for Social Innovation, 2015): 1) exchange of ideas and values; 2) shifts in roles and relationships; 3) integration of private capital with public and philanthropic support.

\section{Conclusion}

Social innovation achieves a systematic change for the benefit of people and planet by using specially adjusted methods for an identified social challenge. Social innovation methodology and its usage in management education setting proved to be an under-researched and highly useful didactic tool to empower students about global and local management issues.

Limitations of our study go in line with a limited sample size on one Business School in Slovenia. Further research direction is proposed to go in spreading the sample on Business Schools in the region and research the social innovation development in the region.

\section{References}

1. Avery, G. C., Bergsteiner, H. (2011). "Sustainable leadership: honeybee and locust approaches", Routledge, New York.

2. Bertoncelj, A., Meško, M., Naraločnik, A., \& Nastav, B. (2011), "Trajnostni razvoj organizacije: ekonomski, družbeno-politični in ekološki vidiki", GV založba, Zbirka Manager, Ljubljana.

3. Boss, S. (2016), "A Slick Vehicle for Street Food", Stanford Social Innovation Review, Vol. 14 No. 1, pp. 8-9.

4. Denzin, N. K., Lincoln, Y. S. (2005), "The Sage Handbook of Qualitative Research", Sage Publications, Inc., Thousand Oaks.

5. Goldsmith, S. (2010), "The power of social innovation", John Wiley \& Sons, Inc., San Francisco.

6. Hargreaves, A., Fink, D. (2006), "Sustainable leadership", John Wiley \& Sons, San Francisco.

7. Kezar, A. J., Lester, J. (2011), "Enhancing Campus Capacity for Leadership: An Examination of Grassroots Leaders in Higher Education", Stanford University Press, Stanford.

8. Klein, J.-L. (2015), "Introduction: social innovation at the crossroads between science, economy and society", in Moulaert F., MacCallum, D., Mehmood, A., Hamdouch, A. (Eds.), The International Handbook on Social Innovation: Collective Action, Social Learning and Transdisciplinary Research, Edward Elgar Publishing Limited, Cheltenham, pp. 9-12.

9. Konstantatos, H., Siatitsa, D., Vaiou, D. (2015), "Qualitative approaches for the study of socially innovative initiatives", in Moulaert F., MacCallum, D., Mehmood, A., Hamdouch, A. (Eds.), The International Handbook on Social Innovation: Collective Action, Social Learning and Transdisciplinary Research, Edward Elgar Publishing Limited, Cheltenham, pp. 274-284.

10. Kunnen, N., MacCallum, D., Young, S. (2015), "Research strategies for assets and strengths based community development", in Moulaert F., MacCallum, D., Mehmood, A., Hamdouch, A. (Eds.), The International Handbook on Social Innovation: Collective 
Action, Social Learning and Transdisciplinary Research, Edward Elgar Publishing Limited, Cheltenham, pp. 285-298.

11. Moulaert, F., MacCallum, D., Hillier, J. (2015), "Social innovation: intuition, precept, concept, theory and practice", in Moulaert F., MacCallum, D., Mehmood, A., Hamdouch, A. (Eds.), The International Handbook on Social Innovation: Collective Action, Social Learning and Transdisciplinary Research, Edward Elgar Publishing Limited, Cheltenham, pp. 13-24.

12. Moulaert, F., MacCallum, D., Mehmood, A., Hamdouch, A. (2015), "General introduction: the return of social innovation as a scientific concept and a social practice", in Moulaert F., MacCallum, D., Mehmood, A., Hamdouch, A. (Eds.), The International Handbook on Social Innovation: Collective Action, Social Learning and Transdisciplinary Research, Edward Elgar Publishing Limited, Cheltenham, pp. 1-6.

13. Murray, R. Caulier-Grice, J., Mulgan, G. (2010), "The Open Book of Social Innovation", NESTA: The Young Foundation.

14. Osburg, T., Schmidpeter, R. (2013), "Social Innovation: Solutions for Sustainable Future", Heidelberg, Springer.

15. The Centre for Social Innovation (2016), available at:

http://www.gsb.stanford.edu/faculty-research/centers-initiatives/csi (5/5/2016)

\section{About the authors}

Judita Peterlin, Ph.D. is an Assistant Professor of management and organizational theory working as a research and teaching assistant at the Faculty of Economics, University of Ljubljana. She graduated from the Faculty of Social Sciences and Faculty of Economics University of Ljubljana. In the study year 2014/15 she is a teaching assistant at the following courses: Foundations of management and organization, Management - English Track, Knowledge management, and Advanced management. Her main research interests are: social innovation, leadership development, sustainability. Author can be contacted at judita.peterlin@ef.uni-lj.si.

Vlado Dimovski, Ph.D. is a Full Professor of management and organizational theory at the University of Ljubljana, Faculty of Economics in Slovenia. He received his B.A. degree in Economics at the University of Ljubljana, the B.A. degree in Philosophy at the University of Ljubljana, the M.A. degree in Economics at University of Ljubljana, and the Ph.D. degree in Management and Finance at Cleveland State University. His primary areas of expertise are organizational learning, management, organizational behavior and leadership. He conducts research on knowledge management and organizational learning process and regularly provides consulting about organizational learning for business entities. Author can be contacted at vlado.dimovski@ef.uni-lj.si.

Daniela Garbin Praničević, Ph.D. is an Assistant Professor of business informatics at the Faculty of Economics, University of Split. In the named Faculty, she received her B.A. degree in Economics. Her M.A. degree is received in Information Management at the Faculty of Economics, University of Zagreb, and the Ph.D. degree in Business Informatics at the Faculty of Economics, University of Split. Her research interests are knowledge management, IT project management, and IT appliance in business, particularly in tourism and hospitality. She participated in few research projects and published papers based on the project results. Author can be contacted at daniela@efst.hr. 